\title{
Monetary channels of social inclusion: a case study of basic income and the Caixa Econômica Federal in Brazil
}

\author{
Kurt Eberhart von Mettenheim \\ FGV-EAESP \\ Maria Fernanda Freire de Lima \\ FGV-EAESP
}

\begin{abstract}
This article reports evidence of new monetary channels for social inclusion involving basic income policies and the Caixa Econômica Federal, a Brazilian government savings bank. Since the Plano Real (Brazilian currency) and the liberalization of banking in the 1990s, the realization of competitive advantages by the Caixa as social policy agent and the importance of citizenship cards differ from existing theories of bank change, financial inclusion and monetary policy. Multi-method research reveals the importance of 1) political theories of basic income, 2) conceptions of citizenship and social justice, and 3) a back to the future modernization of government banking. This provides alternatives to contemporary market-based banking theory, neo-liberal policies, private and non-governmental microfinance strategies, and theories in political economy about fiscal constraints to social policies. New monetary channels of change also suggest that zero sum theories about politics, monetary authority and social inclusion are amiss.
\end{abstract}

KEYWoRDs: monetary policy; financial inclusion; savings banks; Brazil.

Canais monetários de inclusão social: um estudo de caso de renda mínima e a Caixa Econômica Federal

Este artigo reporta evidências sobre novos canais monetários de inclusão social envolvendo políticas de renda mínima e a Caixa Econômica Federal. Desde o Plano Real e a liberalização do sistema bancário na década de 1990, a realização de vantagens competitivas pela Caixa ao servir de agente de políticas

DOI: http://dx.doi.org/10.1590/0034-76121500

Article submitted on 12 mar. 2013 and accepted for publication on 27 jun. 2014.

Acknowledgments: Support for field research in 2010 was provided by GVpesquisa and the University of California, Irvine Institute for Money, Techology and Financial Inclusion. Further support for research in Goias, conducted by Natalia Fingermann, Raphael Knirsch and Matheus Braz, was provided by the FGV-EAESP Conexão Local program. Researchers in Guaianases: Alberto Kim, Anna Mortara, Erika Miyamura, Havner Haenchke, Lais Trajano, Laurent Broering, Leonardo de Siqueira Lima, Mariana Garcia, and Mateus Lopes. 
sociais difere de teorias de mudança bancária, de inclusão financeira e de política monetária. Pesquisas multimétodo revelam a importância de 1) teorias políticas de renda mínima, 2) concepções de cidadania e de justiça social e 3) uma modernização "volta ao futuro" de bancos públicos. Isso proporciona alternativas à teoria contemporânea bancária, às políticas neoliberais, às estratégias de microfinanças privadas e não governamentais e às teorias na economia política sobre limites estruturais e fiscais para políticas sociais. Esses novos canais monetários também contrariam teorias de natureza soma zero entre a política, a autoridade monetária e a inclusão social.

Palavras-chave: política monetária; inclusão financeira; bancos de poupança; Brasil.

Canales monetarios de la inclusión social: un estudio de caso de la renta mínima y las políticas de la caja de ahorros pública en Brasil

Hay pruebas de nuevos canales monetarios de inclusión social relacionados con la renta mínima y la caja de ahorros pública en Brasil. Desde la estabilidad de precios y la liberalización de los servicios bancarios, la realización de ventajas competitivas de una caja de ahorros pública, agente de política social y inclusión bancaria, difiere de las teorías dominantes de cambio bancario, inclusión financiera y política monetaria. Una encuesta revela la importancia de 1) las políticas de renta mínima, 2) conceptos de ciudadanía y justicia social, 3) la modernización del banco público y social. Los resultados presentan alternativas a las políticas neoliberales, basadas en los mercados de capitales y la banca privada. Nuevos programas para inclusión bancaria sugieren que las teorías de dominancia fiscal, los límites estructurales y las relaciones de suma cero entre la política monetaria y la inclusión social necesitan ser revisadas.

Palabras clave: política monetaria; inclusión financiera; cajas de ahorro; Brasil.

\section{Introduction}

Contrary to expectations about private banks and microfinance, basic income grants and a federal government savings bank have instead proved more effective mechanisms for financial inclusion in Brazil. This article reports evidence from new research, scenario construction, market shares and bank performance, micro level data from credit portfolios, bank branch offices and correspondents, and in-depth field research including 182 interviews in Guaianases, São Paulo and three municipalities in Goiás. Multi-method research tested, empirically and theoretically, competing theories about financial inclusion; those emphasizing the greater efficiency of private banking and non-governmental microfinance organizations and, in opposition, new theories that emphasize the institutional foundations of competitive advantage of alternative banks (Butzbach and Mettenheim, 2014), the importance of conceptions of citizenship and social justice, and the mix of basic income grants and savings bank services. Strong evidence suggests that basic income grants and government savings bank policies have proven far more effective than private banks or non-governmental microfinance organizations in promoting financial inclusion in Brazil.

This counters widely accepted theories of monetary policy and fiscal constraints to change. Monetary theory and policy usually assume zero sum relations between social in- 
clusion and central banking. To the contrary, positive sum relations may obtain in contexts of inequality and financial exclusion such as Brazil; this reverses standard views of politics, money, banking and central banks. Instead of seeking to secure central bank independence from politics and society (Alesina and Summers, 1993) or free markets through privatizations and liberalization (Williamson, 1990), the construction of monetary authority in Brazil (Sola and Whitehead, 2006) was achieved through incremental statecraft, heterodox anti-inflation policies, and realization of policies with and competitive advantages by government banks (Mettenheim, 2010). Since 2000, state banks, basic income policies (albeit conditional, see Soares et al., 2010) and other social policies have proved to be the predominant mechanism for reaching vast numbers of bankless Brazilians (Mettenheim et al., 2013). Conceptions of citizenship and social justice (Leão Rego and Pinzani, 2013; Brandtstädter et al., 2011) therefore provide alternatives to ideas about entrepreneurship and free markets as keys to financial inclusion. New social policies, central bank modernization, and reform of government banks have helped reverse social exclusion, improve monetary authority and maintain price stability amidst democratization in Brazil.

These monetary channels of change differ from past experiences. Since the 'end of the electoral road to socialism,' exemplified by military coup against President Salvador Allende in Chile in 1973, social scientists and policy communities have focused on fiscal constraints to social policies. For Gold, Lo and Wright (1975), new structural theories of the state improved on instrumental and functional theories by describing how individual investors price markets, limit social policy spending and veto change; because government policies require either tax increases or budget cuts, social policies may become counterproductive by reducing the profits of firms and, in turn, tax revenue and public funds. This vicious cycle, in the worst cases, contributed to political-economic crisis and the breakdown of democracy in developing countries (O'Donnell, 1973). Similar forces in advanced economies, from this perspective of fiscal constraints, produced stagflation in the 1970s and electoral turns to neo-conservative politics to dismantle Welfare States (Pierson, 1996; Przeworski, 1985).

These explanations are now incomplete. Old views of fiscal dominance and structural constraints to change fail to account for advances both in monetary economics during the 1990s and monetary policy making during the 2000s (Bernanke and Gertler, 1995). Central bank modernization, new regulatory frameworks, and better supervision of banks and markets (despite opting for deregulation in the US and select tax havens and financial centers) provide a new setting for monetary channels of change and financial roads to more social economies. Structural theories of the state and conceptions of hard fiscal constraints predate modern studies of credit channels and interest rate channels. Since the 1990s, new concepts from monetary economics have improved central banking and monetary policy making; they also require rethinking constraints to change and social policy.

We focus on how monetary channels provide new opportunities, and risks, for social policy, public banking and financial inclusion. Many developing countries have accumulated large stocks of foreign reserves through sustained trade surpluses to overcome past vulnerabilities. Moreover, in Brazil, transparent policy frameworks such as inflation targeting, tou- 
gh fiscal targets, and a flexible foreign exchange regime have remained in place since 1999 (Fraga et al., 2004). The current situation of Brazil and many developing countries is thus different from the 1970s. In Brazil, the modernization of state banks (after mismanagement under military rule and capture by oligarchs during prolonged transition), and a sequence of economic reforms have approximated government policies and markets to provide new channels for financial inclusion.

A case study clarifies how the Caixa Econômica Federal (Caixa) functioned, in this new context, both as agent of federal government social policy and savings bank to promote financial inclusion. The Caixa developed new channels such as simplified accounts, electronic card technology, and correspondent banking to deliver income grants and modernize social policy provision, thereby proving citizens with access to banking and public services in vast numbers. Since transition from military rule and price stability (1994), financial liberalization (1995) and incorporation of new banking technologies during the 2000s, public banking, social policies and conceptions of citizenship and social justice have proved more much effective to reach bankless Brazilians than private banks or microfinance firms, funds, or organizations.

This is an anomaly for neo-liberal policies, contemporary banking theory, and the international microfinance movement that abhors state banks in favor of private initiative, philanthropy and non-governmental organizations. However, the record in Brazil and beyond is now clear. Since liberalization of banking systems during the 1990s and 2000s, government banks (where they were not privatized) have remained dominant players in many developing economies, especially the largest ones (Mettenheim, 2014). Instead of transitions to private, market-based banking (Hardie and Howarth, 2013), state banks have instead realized competitive advantages over private and foreign banks to remain central agents of credit, finance and public policy. Indeed, the modernization of government banks during the 2000s occurred just in time to counter crisis in 2008. The capitalization, reform and reorientation of large public banks provided policy makers in many developing countries with counter cyclical policy alternatives once global crisis hit (Schclarke Curutchet, 2014). State banks have also proved critical agents for financial inclusion. This article reports evidence of how a federal government savings bank provided new channels for social policies based on conceptions of citizenship and social justice in Brazil. Our findings build on the rich research and policy debates about microfinance and financial inclusion in Brazil as can be seen in the proceedings of Central Bank of Brazil seminars on microfinance (1999-2008) and Financial Inclusion (2009-) and (Franca Filho et al., 2012; Monzoni, 2008; Neri, 2008; Magalhães and Abramovay, 2007; Mattei, 2002).

\section{From Keynesian demand management to reaching the bankless}

Monetary channels, basic income and public bank agency also differ from aggregate demand management traditionally pursued by working class parties. New policies of social and state banking aim to improve provision of social services and increase access to banking services. 
Supply side policies are usually associated with neo-liberalism and neo-conservatism. However, recent strategies suggest different political correlates. Since liberalization of banking in many developing countries, state banks have outperformed private and foreign banks by mixing provision of banking services and social services to reach large numbers of unbanked citizens to help reverse inequality and social exclusion. These policies involve microeconomics of social inclusion and differ fundamentally from the macroeconomics of populism, and fiscal constraints, in the past (Dornbusch and Edwards, 1991).

Monetary channels of change also differ from concerns in studies of central banking and monetary policy in advanced economies that assume banked populations, zero-sum games, and profit maximizing actors amidst stable prices and economies. Stark inequalities in developing countries provide large marginal gains from financial inclusion that improves monetary authority. For example, compare Brazil in the 1990s and the 2000s. To regain market confidence during financial crises in the 1990s, the Central Bank of Brazil increased SELIC benchmark overnight interbank interest rates to 42 per cent (Mexico, 1994-5; Asia 1997; Russia, 1998; Brazil 1999). Progress can be seen by recourse to 23 per cent interest rate hikes during crises in the early 2000s (Argentina, 2001; Brazil, 2003) and 12 per cent (7 per cent real) rates adopted in 2008-9 to counter crisis abroad. Worse begets better. The relation between politics, social inclusion and monetary policy here is not a zero-sum game optimized by legislating central bank independence. Instead, the construction of monetary authority (after decades of inertial inflation and monetary chaos in Brazil) reaps large marginal returns from reforms and declining, albeit still high, costs of adjustment.

Monetary policies and social inclusion are also positive sum because the large number of Brazilians brought within credit and interest rate channels improves the effectiveness of policy. In 2000, an estimated 20 per cent of Brazilians had bank accounts. Central bank interest rate policies and government credit policies therefore failed (directly) to reach 80 per cent of citizens that remained outside channels of credit and interest rates. By 2010, the number of Brazilians with bank accounts had increased to an estimated 45 per cent (still roughly half levels found in most advanced economies). Notwithstanding the remaining challenges for financial inclusion, doubling the number of Brazilians with bank accounts 2000-10 has been fundamental both for social inclusion and improving monetary policy.

Monetary policy frameworks (such as inflation targeting, the Taylor rule and models of dynamic general equilibrium) and central bank monitoring and supervision of credit flows and the portfolios of banks and credit institutions provide new means to monitor market signals and inflation that set limits to basic income payments, social policies and down-market credit programs such as popular home mortgage finance. This differs from both theories of hard fiscal constraints and the primary concern of economists about monetary policy shocks. Research on central banking, monetary theory, and channels of credit and interest rates assume the contexts of advanced economies with banked populations and mature markets for loans and bonds. These assumptions do not hold in developing countries if 80 per cent of citizens remain bankless and shallow bond markets restrict issues to a select number of corporate issuers and the central government. 


\section{Finance and inequality}

Two broader concerns about finance and inequality suggest the importance of monetary channels of change. First, in a context of high financial returns and inequality such as Brazil, finance is transformed from phenomena that, in other contexts, may smooth consumption and investment across generations and social groups into a mechanism that increases inequalities. Second, we estimate the time needed for Brazil to reach levels of financial inclusion typical of advanced economies under four different policy frameworks. Frameworks based on private banking fare the worst.

First, regarding finance and inequality, Table 1 projects financial returns of 10 per cent from 2000-2040 based on average incomes of population quintiles in 2000 estimated by the São Paulo Municipal Atlas (Prefeitura de São Paulo, 2000). Figures for 1991 and 2000 are average monthly incomes compiled from census data. Declines for lower income quintiles 1991-2000 suggest reverses typical of periods of economic reform and, presumably, the result of migration to metropolitan São Paulo. After 2000, hypothetical figures are calculated by simply adding 10 per cent per year to income quintiles (and the top 10\% income cohort) across decades. The result from these scenarios is clear: Financial returns on personal assets dramatically increase inequalities.

Table 1

Simulation of lifetime personal asset accumulation by income quintiles for São Paulo city, 1991-2040, R\$

\begin{tabular}{|lllllll|}
\hline Year & $1 / 5$ & $2 / 5$ & $3 / 5$ & $4 / 5$ & $5 / 5$ & $>10 \%$ \\
\hline 1991 & 956.8 & $2,143.2$ & $3,496.1$ & $5,993.8$ & $19,587.2$ & $28,623.8$ \\
2000 & 735.7 & $1,965.4$ & $3,424.0$ & $6,353.4$ & $24,124.2$ & $36,022.0$ \\
2010 & $1,908.3$ & $5,097.6$ & $8,880.9$ & $16,479.1$ & $62,572.0$ & $93,431.7$ \\
2020 & $4,949.6$ & $13,222.0$ & $23,034.7$ & $42,742.5$ & $162,295.6$ & $242,337.7$ \\
2030 & $12,837.9$ & $34,294.4$ & $59,746.1$ & $110,863.0$ & $420,952.9$ & $628,561.7$ \\
2040 & $33,298.1$ & $88,950.7$ & $154,965.9$ & $287,550.2$ & $1,091,843.3$ & $1,630,327.1$ \\
\hline
\end{tabular}

Source: Prefeitura de São Paulo (2000).

Note: Authors calculations based on quintiles and top 10 per cent income in Municipal Atlas. 1991 and 2000 baselines are average monthly income for each income quintile. Figures from 2020-40 report composite annual returns of 10 per cent.

This exercise suggests that finance increases inequality in settings of inequality and high financial returns, one typical of many developing countries. Indeed, given that most Brazilians have little or no income to save and that 55 per cent still had no bank account in 2010, this exercise underestimates the extent to which finance increases inequality. In sum, from the notorious starting point of Gini Coefficients for Brazil in 1990 (0.60), the reality of geometric financial returns over time can be said to multiply inequality significantly. 
Figure 1

Financial inclusion in Brazil at current pace, 2000-2030

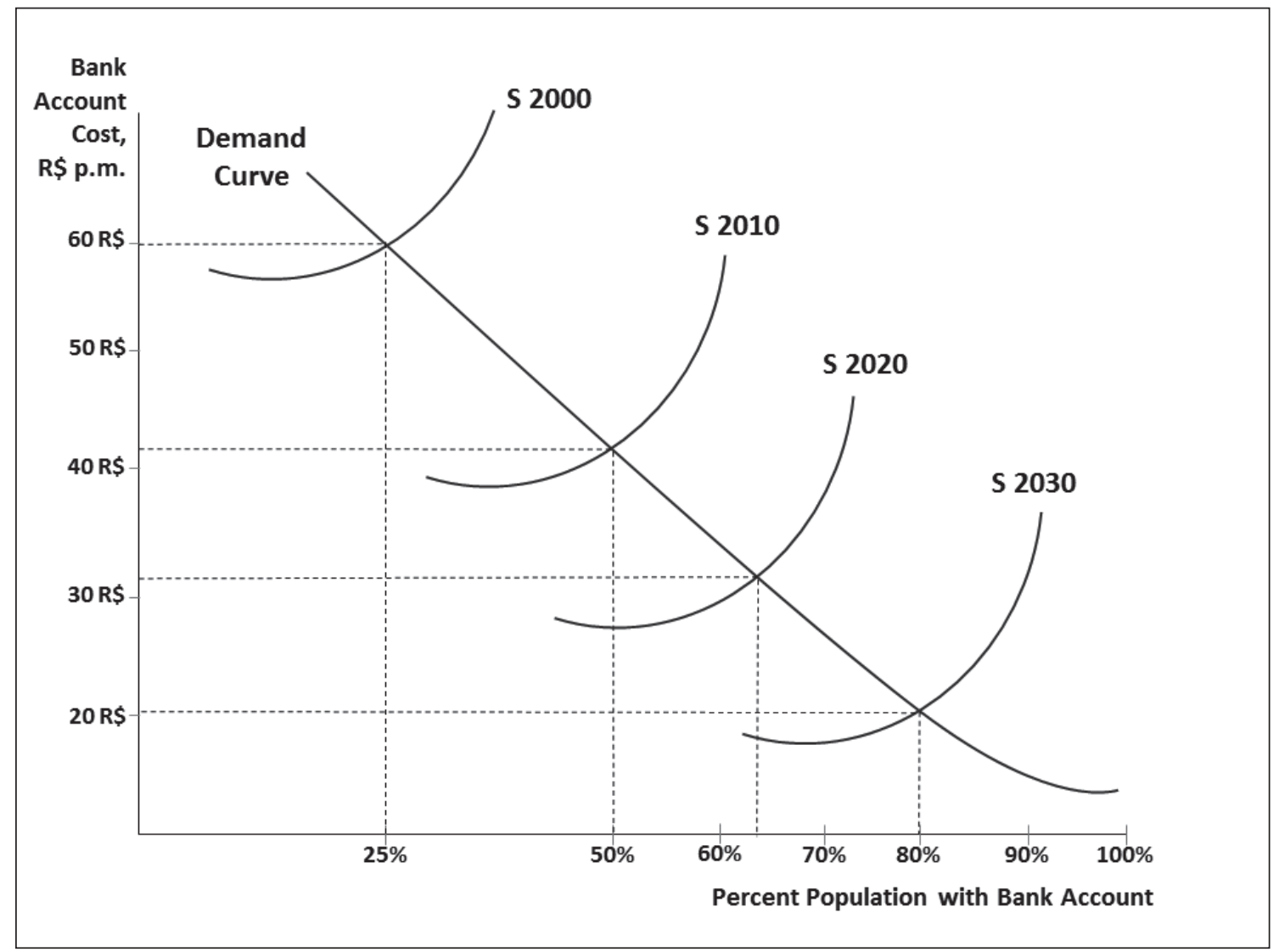

Source: Elaborated by authors.

A second theoretical exercise suggests that private banking in Brazil is insufficient to promote financial inclusion. Figure 1 extrapolates the recent pace of bank inclusion in Brazil from 2000-10 for the decades 2010-30. Linear projection suggests that reaching levels of bank inclusion typical of advanced economies (say 80 per cent), will take another two decades.

To consider alternatives, compare four supply curve scenarios for the banking market in Brazil in 2030 reported in figure 2. Scenario one suggests that, according to the private bank supply curve, bank accounts would remain at 33 per cent of the population (100 of 300 million Brazilians). In comparison, in scenario three the lower supply curve of savings banks that specialize in simplified (no-cost, 'no-questions-asked') bank accounts would reach roughly 66 per cent or 200 of 300 million Brazilians. Scenario one estimates the number of bank accounts one can expect from more expensive, up-market supply curves of private banks; roughly five per cent or 60 million of the population projected for Brazil in 2030. 
Figure 2

Four supply curve scenarios for Brazilian bank market, 2030

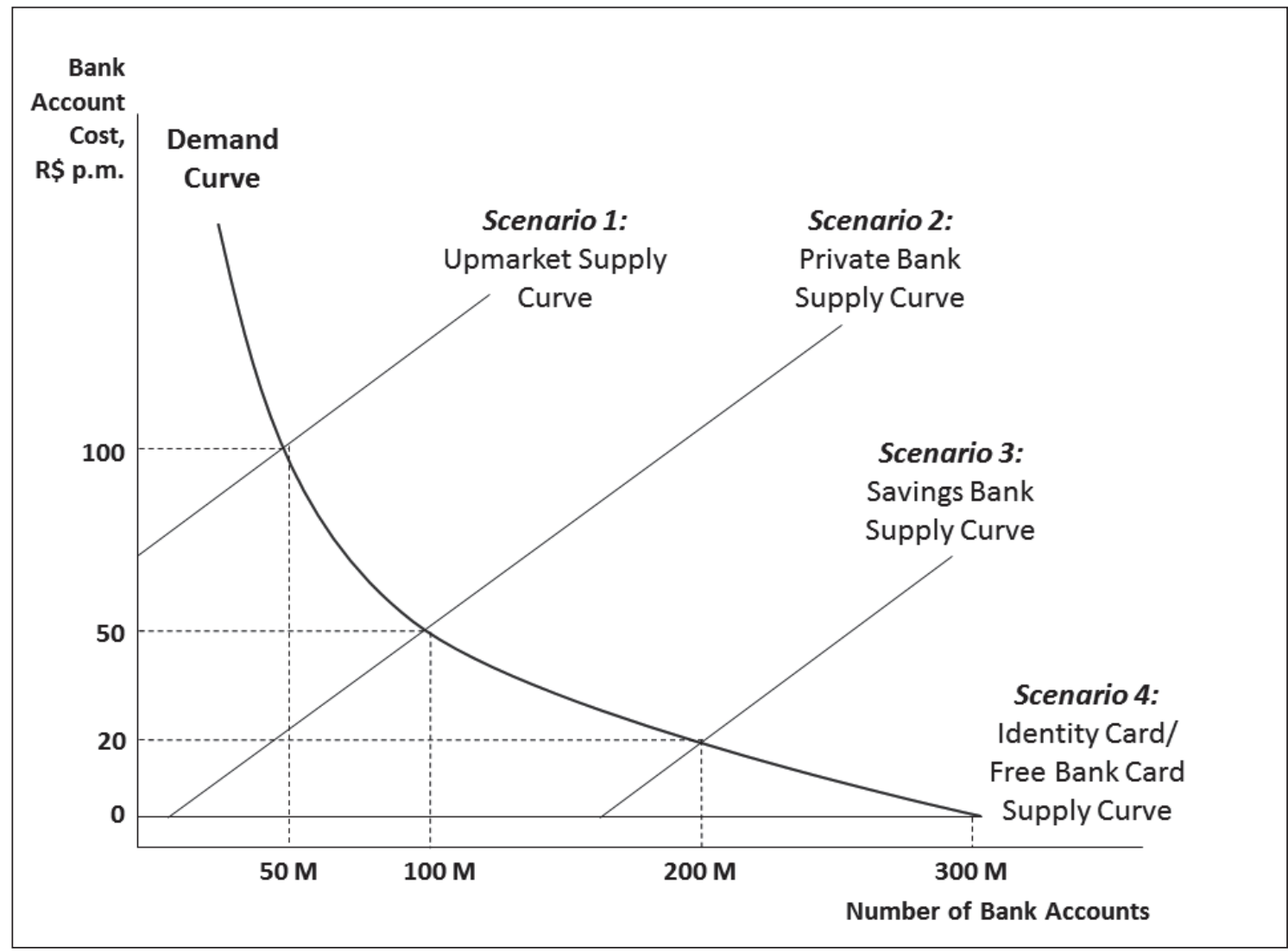

Source: Elaborated by authors.

The fourth scenario is based on recent experiments with issue of identity cards as nocharge bank cards. This supply curve at zero cost (to users) is horizontal. Accordingly, full bank inclusion of all Brazilians could be completed well before 2030. These theoretical scenarios suggest that private banks are sub-optimal for financial inclusion.

These general concerns about finance and inequality leverage the importance of our findings about public banking, basic income policies and new monetary channels for change. However, before turning to field research evidence, an introduction to the Caixa is in order.

\section{Back to the future of public savings banks}

Founded in 1860, the Caixa retained, in September 2013, over US\$ 384 billion in assets, 123,969 employees, 3,176 branch offices and a 17.0 Basel Accord Capital Adequacy Ratio 
(Central Bank of Brazil, 2014). Comparison of Caixa performance with private banks; analysis of balance sheets, branch office level data and point-of-sale traffic in branch offices and bank correspondents; and interviews with over 182 clients, staff and management of the Caixa and other banks confirm previous case studies (Mettenheim, 2006) and comparative (Ayadi et al., 2010) findings that many public savings banks have realized competitive advantages over private and foreign banks (even, and especially, after liberalization of national banking systems). This counters expectations that opening banking and credit markets would lead to the dominance of private and foreign banks and provides new concepts, theories, and policy alternatives that avert biases in microfinance toward private banks, non-governmental organizations and market funding.

In Brazil, since transition to democracy, the end of inertial inflation (1994), liberalization of banking (1995) and capitalization of federal government banks to meet Basel Accord I requirements (2001), the Caixa has consistently outperformed private and foreign banks in terms of profits, returns, non-performing loans and a variety of standard indicators. The Caixa used large scale institutional foundations of competitive advantage (Hall e Soskice, 2001) to reform and modernize during transition to international regulations and new central bank policies of supervision and control. Critics of government banking emphasize political capture (La Porta et al., 2002). The Caixa (and other Brazilian government banks) did indeed suffer mismanagement under military rule (1964-85) and were captured by traditional elites during the prolonged transition to democracy (1974-94). However, since 1994, Caixa management has used institutional foundations of competitive advantage to outperform private and foreign banks amidst more open, transparent and better regulated markets for banking, credit and finance.

In this sense, modernization of Caixa savings bank operations and concessions for government policy implementation proved complementary (Mettenheim, 2006). Family grants, other social services (unemployment insurance, social security, and payroll savings funds), and microfinance programs have been widely credited with reducing notorious levels of inequality in Brazil (Monzini, 2008; Neri, 2008). The Caixa retains most government concessions to manage these policies. This helps bring citizens and prospective clients into Caixa points of sale and expand branch offices and bank correspondent networks cheaper than private and foreign banks. For example, since federal government social policy transactions were consolidated into a single Cartão do Cidadão (Citizenship Card) in the early 2000s, the Caixa won contracts to distribute over 130 million Citizenship Cards. This provides competitive advantages for the Caixa and opportunities for financial inclusion. The Caixa requested permission from the Central Bank of Brazil to transform Citizenship Cards into bank cards. Although denied, this would roughly double the number of bank cards in the country and increase the pace of financial inclusion.

Simplified bank accounts and correspondent banking are further innovations that have mixed social policy agency and public banking to promote financial inclusion in Brazil. 


\section{Simplified bank accounts}

The Central Bank of Brazil introduced rules for simplified bank accounts in 1999 to reduce barriers that kept roughly 80 per cent of citizens bankless. Banks were initially required to accept applications for simplified accounts upon presentation of Brazilian identity cards (neither proof of income nor residence necessary). If clients of simplified accounts retained a positive balance for 90 days, then they became eligible for loans up to $\mathrm{R} \$ 200$ (with no further information from clients nor credit analysis). Moreover, positive balances for two further 90 day periods increased credit lines to $\mathrm{R} \$ 600$ - still without any information about clients except for identity card numbers. Simplified accounts at the Caixa (Table 2) reached 8.75 million by 2010. Caixa market share of simplified accounts increased 58-87 per cent 2004-10. Most private banks no longer offer simplified accounts.

Table 2

Simplified bank accounts, 2004-10

\begin{tabular}{|lccccc|}
\hline & Caixa & Total & Caixa Market Share & Active Accounts & Active as \% Total \\
\hline 2004 & $1,100,000$ & $1,897,828$ & $58 \%$ & $1,882,648$ & $99 \%$ \\
2005 & $2,200,000$ & $4,275,309$ & $51 \%$ & $4,117,667$ & $96 \%$ \\
2006 & $3,100,000$ & $6,443,218$ & $48 \%$ & $4,467,924$ & $69 \%$ \\
2007 & $3,900,000$ & $6,806,375$ & $57 \%$ & $4,520,620$ & $66 \%$ \\
2008 & $4,700,000$ & $7,693,608$ & $61 \%$ & $4,424,697$ & $58 \%$ \\
2009 & $7,000,000$ & $9,966,535$ & $70 \%$ & $5,644,471$ & $57 \%$ \\
2010 & $8,750,000$ & $10,056,674$ & $87 \%$ & $5,612,934$ & $56 \%$ \\
\hline
\end{tabular}

Source: Caixa Annual Reports and Central Bank of Brazil.

In comparison, the Caixa offered simplified accounts to family grant recipients enabling direct-deposit of basic income grants, providing bank accounts, for the first time, to most (women) recipients of family grants. Direct debit of family grants into simplified bank accounts (no charges, no questions asked) eliminates the need to appear in person at the branch office, reduces risk of theft, facilitates payments for goods and services by card instead of cash, and provides proof of address, often for the first time, so that women may apply for further services.

In 2010, the Caixa began to automatically extend overdraft privileges if simplified account balances remained positive. This effectively transforms a simplified bank account into a payroll credit - on per-monthly basic income grants of R\$ 36-306 (US\$ 18-153 in February 2013). Further research into family grants and simplified accounts as gender based social policy for financial inclusion will be required (Leão Rego and Pinzani, 2013). However, this combination of basic income, social policy and government savings bank operations are fundamentally different phenomena than expected by mainstream and critical theories; i.e. the 
predominance of private banking after financial liberalization. Use of bank correspondents by the Caixa also differs from these expectations.

Finally, the number of simplified savings accounts decreased to 6,031 in June 2010, after reaching 230,000 in 2006. This suggests the difficulty of expanding financial inclusion. Interviews with Caixa staff and clients and the aggregate data on income declines among lower income quintiles confirm the difficulty of accumulating savings, the importance of basic income policies, and the difficulty of market centered policies for financial inclusion.

\section{Doubly decisive case studies for social banking: Guaianases and Goiás}

Caixa branch offices and correspondents in East End São Paulo and three municipalities in Goiás state were chosen for in-depth field research because they provide "doubly decisive" case studies (Collier, 2011:825) best suited to test theories about financial inclusion. Recent advances in case study selection method and in-depth field research design forsake randomization necessary for statistical analysis and adopt, instead, more powerful research methods to test competing theories and leverage causal inferences (Goertz and Mahoney, 2012; Steinberg, 2007; Bennet and Elman, 2006; George and Bennet, 2005; Collier et al., 2004; Ragin, 1987; Eckstein, 1975; Lijphart, 1971; Przeworski and Teune, 1970). Field research on Caixa policies and performance in Guaianases and Goiás state were thereby designed to test our claims about monetary channels for social inclusion and control for competing theories about fiscal constraints and private sector based microfinance. Setting the context is the first step in conducting such effective case studies through field research.

Until occupation by farmers in the 1910s, the São Paulo district of Guaianases retained open forest and Guaianás indigenous villages first grouped by Jesuits along the Jacu tributary of the Tiete river. The Ferro Norte railway in the 1940s and industries built along the Dutra highway (São Paulo to Rio de Janeiro) during the 1950s transformed Guaianases into a working class dormitory suburb. Census data from 2000 place Guaianases as the third poorest district in São Paulo. Per-capita income of Guianases residents increased slightly (239.6-246.9 R\$ per month 1991-2000) but remained less than half averages recorded for São Paulo city.

Census data clarifies the context for social and public banking in Guaianases. Public income transfers increased from 5.7-10.3 per cent of total income of the district from 19912000; while residents for whom transfers exceeded 50 per cent of income increased from 3.8-8.3 per cent of the population. Indicators of human development in Guaianases increased slightly (0.739-0.768 1991-2000), but fell further behind averages for São Paulo city (0.8050.841 1991-2000). Family vulnerability indicators also increased. Women aged 15-17 with children increased from 3.59-7.4 per cent (São Paulo average 3.8-5.9 per cent); the number of indigent residents rose from 4.6-8.6 percent (São Paulo average $=2.9-5.6$ per cent); the poor increased from 12.8-19.4 per cent (São Paulo average $=8.0-12.0$ per cent); and indigent children increased from 5.9-12.4 per cent (São Paulo average $=4.2-9.0$ per cent 1991-2000). The 
number of children in school did increase substantially 1991-2000, but advances in primary and secondary education stand in stark contrast to the lack of access to college education.

The Caixa branch office in Guaianases is also a 'frontier' for banking because crime in Cidade Tiradentes to the east makes bank branch office operations impossible (five armed assaults on the Guaianases office occurred 2007-10). The Caixa branch office in Guianases thus serves roughly 500,000 East End residents, managing 10,500 family grants, 9,500 public pensions, 2,768 current accounts and 339 business accounts in 2010. Traditional savings accounts remain the principal product of the Caixa and provide a secure liability base. Savings accounts numbered 34,402 (with R \$ 36.2 million deposits, i.e. R\$ 105 or US\$ 53 average). In comparison, 61 business savings accounts summed to $\mathrm{R} \$ 101,081$. Payroll loans also stand out (1,535 loans averaging $\mathrm{R} \$ 4,180$ summing to $\mathrm{R} \$ 6,420,497)$ and personal direct credit (513 loans averaging $\mathrm{R} \$ 1,550$ summing to $\mathrm{R} \$ 795,031$ ). The predominance of personal savings accounts with low balances and few business accounts confirms the mission of the Caixa as a public savings bank.

Above, we suggest that the mix of down-market savings bank operations and provision of social services provides the Caixa with competitive advantages. This mix can be seen in the profile of Caixa customers that come through the door of the Guaianases branch office. Counts of customers served and interviews at the Guaianases branch office recorded an average of 119 services per hour: 87 involved social policy while 32 involved banking (Table 3).

\section{Table 3}

\section{Social vs banking services at Guaianases Caixa Branch Office}

\begin{tabular}{|lc|}
\hline Why at the Bank? & N Services \\
\hline Social Policy & 23 \\
PIS Bonus (despite past deadline) & 30 \\
FGTS Official Payroll Savings & 14 \\
Unemployment Insurance & 9 \\
INSS Social Security & 4 \\
Password registration for Family Grants & 7 \\
Family Grants & 87 \\
Subtotal social policy services & 14 \\
Banking Services & \\
Withdrawals, deposits, transfers, bill payment, statements, bounced cheques, & 11 \\
cloned cards. & 5 \\
Problems with cards, unblock cards & 2 \\
Password registration for cards & 2 \\
Account opening & 32 \\
Sub-total banking services & 119 \\
\hline Total & \\
\hline
\end{tabular}

Source: Field research observations. 
Further evidence of the mix of social policy agency and banking at the Caixa was observed during field research: Between 11-30 July 2011, the Caixa paid over R $\$ 2.9$ billion in bonuses of $\mathrm{R} \$ 510.0$ to over 5.8 million workers (of 28 million eligible) from the Fundo de Amparo ao Trabalhador (Worker's Compensation Fund, FAT) and over 5.6 million bonuses under the Programa de Integração Social (PIS) payroll deduction social security program. Lines at Caixa branch offices grew (in Guaianases to over 40 minute waits) as payments approved numbered one in a hundred inquiries.

Since the $19^{\text {th }}$ century, a key to savings bank performance has been the holding of a large number of small savings deposits. This provides a better liability base compared to private and foreign banks that are subject to market fluctuations and liability risk, especially during crises. From the 1864 bank crisis (only four years after the Caixa was founded) to the 1996 banking crisis, depositors have sought to shift funds from private and foreign banks into Caixa accounts because of greater confidence (deposit guarantees were introduced after 1996). Because public savings banks hold more stable savings deposits and retain greater client confidence, they are better able to sustain counter cyclical lending to help firms and families through downturns. And given their large size, public savings banks also help smooth business cycles better than private or foreign banks.

This implies proper management of credit and finance to avert losses. In this respect, a standard indicator of bank performance is the level of non-performing loans held by banks. During military rule in the 1980s and economic instability in the 1990s, non-performing loans (over 90 days) at the Caixa often reached 30-40 per cent of total loans. However, since transition to democracy (and capitalization of the Caixa in 2001 to meet Bank for International Settlement Basel Accord Capital Reserve guidelines), non-performing loans have fallen under 2 per cent: below average levels of bad loans reported by private and foreign banks operating in the country according to Central Bank of Brazil Financial Stability Reports and Caixa Administrative Reports (Relatórios de Administração).

Moreover, compared to private banks (and development banks), credit risk at the Caixa is spread across a large number of smaller loans. The large number and small value of simplified accounts and crotinho loans ( $<$ R \$ 200/US\$ 100 increments) have proved a less risky credit profile. Comparison of non-performing loans at the Guaianases branch office with other branch offices in East End São Paulo, and Caixa national averages in Annual Reports, suggests that the down-market loan portfolio of the Caixa in Guaianases remains largely similar in terms of late and non-performing loans. In sum, social policy delivery, large volume, low credit- and service-unit value, and little information suggest a pattern of credit deepening at the Caixa Guaianases branch office different than private bank lending. From 2009-10, the Guaianases Caixa branch office reported 18 per cent increase of personal accounts to 46.506 (R\$ 7.0 million) with similar results for 2011. 
Table 4

Non-performing loans in Caixa East End branch offices, 2009-10

\begin{tabular}{|lccccc|}
\hline \multirow{3}{*}{ Branch Office } & & \multicolumn{2}{c}{2010} \\
\cline { 2 - 6 } & Portfolio & September & December & March & June \\
\hline \multirow{3}{*}{ Itaquera } & Personal & 3.63 & 4.68 & 4.50 & 4.45 \\
& Business & 1.76 & 1.73 & 1.70 & 1.65 \\
& Total & 2.91 & 3.56 & 3.46 & 3.42 \\
\hline \multirow{3}{*}{ São Mateus } & Personal & 3.25 & 3.22 & 2.65 & 2.63 \\
& Business & 5.87 & 2.37 & 1.30 & 0.36 \\
& Total & 3.78 & 3.07 & 2.39 & 2.06 \\
\hline \multirow{3}{*}{ São Miguel } & Personal & 5.62 & 4.48 & 3.61 & 3.70 \\
& Business & 1.88 & 11.86 & 2.44 & 1.43 \\
& Total & 4.20 & 7.19 & 3.21 & 2.81 \\
\hline & Personal & 3.84 & 4.04 & 4.13 & 4.03 \\
\hline \multirow{2}{*}{ Penha } & Business & 0.84 & 0.80 & 0.80 & 0.79 \\
& Total & 2.64 & 2.74 & 2.80 & 2.74 \\
\hline & Personal & 3.99 & 4.20 & 4.24 & 4.25 \\
& Business & 2.42 & 2.39 & 2.28 & 1.12 \\
& Total & 3.18 & 3.27 & 2.16 \\
\hline
\end{tabular}

Source: Field research observations.

Note: Guaianases branch office $=$ treatment category by virtue of lower income and social indicators. Other three branch offices $=$ control category.

A popular saying about small Brazilian towns is that 'the mayor, priest, police chief and local bank manager' run things. However, in both areas of field research (three rural municipalities of Goiás state and a sprawling periphery of São Paulo city), evidence suggests that the Caixa tends to bypass traditional local and regional hierarchies as agent for federal government social policies (Estella e Ribeiro, 2008). Simplified accounts, family grants and the mixture of social policy payments alongside banking services provide a different picture than past savings bank practices (Moreira, 2012). The Caixa also manages public housing programs: The Guaianases branch office offers home mortgages up to $\mathrm{R} \$ 23,000$ for public project homes under $\mathrm{R} \$ 64,000$, with peak monthly mortgage payments of $\mathrm{R} \$ 400$. This is consistent with a national trend: Public housing projects have driven home construction in far East End São Paulo (once completed, homes doubled in value 2008-10, despite prohibition of sale). 


\section{Correspondent banking}

Correspondent banking is another innovative mechanism of financial inclusion (Jayo and Diniz, 2013). To reach geographically isolated regions and poor urban areas without bank branch offices, the Central Bank of Brazil freed banks in 2003 to contract provision of seven basic banking services with bank correspondents. Regulation of correspondent banking dates to Central Bank of Brazil Circular 220 (October 1973) and resolution 2.166 (1995), but banks began to sign correspondent bank contracts only after resolutions 3.110 and 3.156 (2003) defined seven services that banks could delegate to correspondent institutions (Diniz, Pozzebon and Jayo, 2008). Institutions such as supermarkets, lottery shops and pharmacies have since helped expand the supply of banking services in Brazil. The number of bank branch offices in Brazil has remained largely stable since liberalization of banking (1995). In comparison, the number of bank correspondents increased from 1,373 to 110,000 by 2010, while ATM machines increased 54,075-150,000 according to the Central Bank of Brazil and Brazilian Federation of Banks (Federação Brasileiro de Bancos, FEBRABAN).

The Caixa retains the second largest network of 32,712 bank correspondents in Brazil. Of four banks with correspondent networks over 10,000, two are federal banks - the Caixa and the Banco do Brasil. Moreover, because Aymore (Santander) correspondents offer loans but not accounts or payment services they remain finance franchises.Caixa correspondents provided limited services from 2003-8. However, the Caixa created three categories of correspondent institutions in 2009 (transactional, business and housing) to promote specialization and expand service. Transactional bank correspondents are typically lottery shops. The Caixa holds a monopoly on lotteries in Brazil (lottery shop licenses are acquired from the Caixa through auctions, with owners represented by a professional association that negotiates terms, prices and payments with the Caixa). In comparison, business and housing correspondents tend to pursue more complex business as intermediaries between clients and Caixa branch offices.

Caixa bank correspondents stand out as channels for payments of family grants and management of social policies. Of 11.92 million payments of family grants in September 2010, 7.86 million were processed at correspondent banking institutions; compared to 1.77 million via direct deposit, 810,000 at ATMs, 140,000 online and 134,000 at Caixa branch offices (Central Bank of Brazil, 2010:20). Dozens of family grant recipients we interviewed expressed their clear preferences for bank correspondents over other channels because of greater proximity and ease of access. These channels for financial inclusion stand far above levels reported by private banks and microfinance operations, both in the areas of field research and in aggregate data discussed above.

In Guaianases, business correspondents are mostly building material shops and depots. In 2010, the Caixa launched a new credit card (Construcard) for sale of credit lines at such correspondents. Managers and staff of business correspondents explained favor of limiting payment transactions to reduce risk of robbery because of cash on hand. Card payments and internet transactions with the Caixa branch office improved security. 
Transactional bank correspondents (mostly Lottery Shops) specialize in providing social payments and basic banking transactions. Supermarket foyers are favored locations for these correspondents because of cheap rental space and dense customer traffic. This helps keep payment channels at local businesses. Managers of correspondents and local business owners consistently cited provision lottery shop correspondents as critical for sustaining local business by reducing the need for citizens to leave the neighborhood. A closer look at Caixa bank correspondents in Guaianases and Goiás clarify how these new channels of financial inclusion work in different ways than private banking and microfinance.

\section{Transactional correspondents}

The Gaivotas Lottery Shop, located in a supermarket foyer, had recently stepped up from a transactional to a business bank correspondent operation in July 2010. First opening in 2001 by obtaining lottery license via auction based on price and proof of ability to meet operational requirements (bids vary from $R \$ 10,000$ to $R \$ 500,000$ for favorable locations in upscale neighborhoods), the Gaivotas bank correspondent remains member of the São Paulo State Lottery Shop Association led by Federal Deputy Alberto Mansur (author of legislation regulating more transparent auctions of census-based lottery concessions). Auction of 77 new concessions 2011-12 with business status in East End Sao Paulo increased the number of Caixa lottery shops serving as bank correspondents in the area from 133-200.

Gaivotas opens 9:00-19:00 with five employees processing 35,000 non-lottery transactions per month receiving, on average, 34 cents per transaction ( $\mathrm{R} \$ 11,900$ total). Commissions on lottery sales ( 8.7 per cent) provide 30 per cent of receipts (lottery sales reach 70 percent of receipts in upscale neighborhoods). Expanding from transactional to business correspondent status was inspired by competition in the form of a Bradesco finance franchise opening directly in front of the lottery shop (placing the finance franchise sales counter a meter from Caixa correspondent clients). Banco do Brasil Credcash popular finance outlets have also opened in supermarket foyers across East São Paulo, leading other Caixa transactional lottery shops to expand into relational (business) bank correspondents. This requires installation of bulletproof glass enclosures and a separate sales counter for bank accounts, savings accounts, loans and funeral insurance. Caixa services and credit lines (and interest rates at half private bank levels) provide competitive advantages for lottery shop correspondents over commercial banks and finance franchise shops. A survey conducted by the São Paulo state lottery shop association found greater client satisfaction and better perceptions of efficiency at lotteries over the branch offices of other banks.

Further research was conducted at the Viver Bem Lottery Shop transactional bank correspondent in central Cidade Tiradentes, also located in a supermarket entrance. A Military Police station, 10 small shops, two retail franchises and a second supermarket comprise this downtown commercial area. Lines at the five cash registers of the lottery shop averaged 30-40 clients for bank transactions and 10 clients at registers for lottery sales. Processing transac- 
tions suffered from incomplete information from clients and difficulties with entry of account numbers and passwords. While five ATM machines were available nearby, bank correspondent cashiers were preferred by those unable to complete electronic payments and transfers.

The mix of social policy and bank-payment transactions also appears in data on point of sale traffic at the Cidade Tiradentes Caixa lottery shop. Fourteen of 58 transactions observed involved social policy payments or deposits. This confirms the complementarity of social service delivery and financial inclusion in Brazil.

\section{Business/relational bank correspondents}

Clients, staff and management were also interviewed at relational (business) bank correspondents. As a 'Caixa Aqui' correspondent, the Depósito Mineirão construction materials shop in downtown Guaianases offered banking (bill payments and transfers $(<\mathrm{R} \$ 500$ per account), withdrawals and deposits) and social services (applications and transactions for social security, unemployment funds, family grants and simplified accounts) The Caixa Construcard credit card was the most important driver of business. An average of ten new bank accounts were opened per month; but decreasingly involved family grant recipients because of proximity to the Caixa branch office downtown. Crime remained a major and costly problem. After four armed assaults in first semester 2010, cash registers were placed behind bulletproof glass.

To provide a tougher test of relational correspondent banking, clients and staff of a second building materials shop eleven kilometers southeast of Guaianases were interviewed. Internet connections to the Caixa branch office permitted payments, bank services and two modes of credit; Construcard and Caixa Fácil loans. Construcard credit between R\$ 800-R $\$$ 3.000 is approved automatically, but larger Caixa Fácil loans require approval at Caixa branch and district offices, often obtained within 10 minutes.

Use of Caixa credit lines soon led to ending business relations with Finasa and other private finance franchises, a broader trend that has let private finance franchise groups to construction lending and specialize instead in consumer and auto lending. This suggests the pricing power and competitive advantages of the Caixa in downmarket construction materials markets. Moreover, finance companies such as BV (Banco Votorantim, acquired by the Banco do Brasil) and Finasa often refuse clients because of income requirements. Meanwhile, Construcard loans ( $\mathrm{R} \$ 400-\mathrm{R} \$ 5.000$ ) were extended by the Caixa in 2009 to 58 month terms, leading bank correspondent sales to increase 30 per cent. Caixa loans accelerated do-it-yourself piecemeal home construction and encouraged material shops throughout East End São Paulo to become Caixa bank correspondents, despite the need to formalize business registry and tax status.

In depth research at three Caixa correspondent establishments confirmed the competitive advantages of mixing provision of social and banking services. Of 119 clients interviewed in Guaianases, only two maintained business accounts. One thirds of services provided were social policy payments and transactions. Interviews with family grant recipients provided 
compelling evidence of newfound perceptions of citizenship, social justice and personal dignity, critical attributes of gendered policies of basic income in Brazil (Leão Rego and Pinzani, 2013; Agenor and Canuto, 2013). Very large numbers are involved. Family grants, currently limited to women and their children who frequent school, reached near 12 million in 2010; providing the exclusive source of income for an estimated 48 million Brazilians, over 25 per cent of the population.

Of 9,275 simplified accounts at the Guaianases branch office, half were opened by family grant recipients. Interviews of dozens of family grant recipients (possible because of call for re-registry during period of field research) provided compelling evidence of the importance of basic income to avert social exclusion, poverty and despair. Visceral and emotional defense of basic income family grants suggest powerful perceptions of citizenship and social improvement among recipients. A federal government savings bank, correspondent institutions, simplified accounts, basic income grants and conceptions of social justice have proven critical mechanisms of financial inclusion in Brazil. The number of Brazilians reached by market based microfinance strategies, non-governmental organizations and private banks pale in comparison.

\section{Caixa correspondents and basic income provision in rural Goiás}

To control for our findings in Guaianases, separate field research in 2010 realized 63 in-depth interviews with local authorities, small business proprietors, staff and management of the Caixa and other banks, and bank clients in three predominantly rural municipalities of Goias state: Colinas do Sul (population 3,999), Alto Paraíso $(6,913)$ and Pirenópolis $(24,111)$. Adjacent to the Chapada dos Veadeiros National Park, GDP per capita (Colinas do Sul, R\$ 5,316; Alto Paraíso R\$ 6,332; Pirenópolis R $\$ 7,656$ ) and Human Development indexes (Colinas do Sul 0.658; Pirenópolis 0.693; Alto Paraíso; 0.713) (UNDP, 2013) indicate the degree of social exclusion. Proximity to the national park has encouraged the growth of tourist related business and services, especially in Pirenópolis and Alto Paraíso that boast infrastructure such as hotels, restaurants, bank branch offices and ATMs. Colinas do Sul lacks such infrastructure. Social policies are markedly present: Family grant recipients comprise 29 percent of the population in Alto Paraíso and 25 percent in Colinas do Sul and Pirenópolis (Ministério de Desenvolvimento Social, 2010).

Goias municipalities provided further tests to compare theories of financial inclusion. Because of its larger size and tourism traffic, Pirenópolis retains three bank branch offices (Banco do Brasil, Bradesco e Itaú) and three Caixa bank correspondents; two located in the central market and another in outlying Jaranópolis. Colinas do Sul retains two Caixa correspondents and a (Banco do Brasil) Banco Postal correspondent, but no private bank points of service. Further evidence of the importance of public services and government banks for financial inclusion can be seen by the refusal of Brazilian private bank Bradesco to renew the Banco Postal correspondence contract won instead by the federal government bank Banco do Brasil in 2011. 
Automatic opening of simplified accounts for family grant recipients by the Caixa in Goiás also confirmed the relation between social policy and financial inclusion. Correspondents report similar mixes of social policy service provision and banking. In Goiás, citizens distant from Caixa correspondents lamented being unable to receive family grants or other social policy payments (or deposits) through other non-Caixa correspondents, necessitating lengthy (and expensive) bus travel to reach Caixa correspondents (reproducing local underdevelopment). In comparison, establishment of a Caixa correspondent in Jaranápolis was praised for overcoming problems of access and encouraging local development. Unlike business correspondents in Guaianases, correspondents in Goiás either failed to offer credit lines or failed to inform prospective clients.

In sum, evidence from field research in Goiás confirmed that financial inclusion in Brazil has occurred primarily through social policy provision, correspondent banking, and simplified accounts. The mix of federal government social policy agency and savings bank services combine to better reach bankless Brazilians. Greater distances in rural settings, and lack of social services at other bank correspondents or branch offices increased the importance of Caixa correspondents. These features were cited repeatedly by mayors and local public officials, small business owners and citizen-clients as critical for improving the welfare of residents and local development by facilitating spending at local businesses.

\section{Conclusion}

Evidence from Brazilian federal savings bank policies and performance and field research on the mix of basic income, social policy provision and public banking in Brazil suggest new channels of financial inclusion. Given recent disappointment with private bank and non-governmental provision of microfinance, the monetary channels of change reported herein involving a government savings bank and social policies provide alternative ideas.

In Brazil, economic reforms, financial liberalization, democratization after military rule, and socio-economic heterogeneity provide a quasi-experimental setting for testing the effectiveness of policies for financial inclusion. Change has differed from the expectations of both mainstream and critical observers. Opening Brazilian banking to foreign competition and privatization of most state government banks sought to dismantle the state-centered banking system built under national-populists (1930-45), developmentalists (1945-64) and military rule (1964-85). However, transition to private, foreign and market-based banking has not ensued. Instead, a back to the future modernization of social and state banking has occurred. The Caixa, a traditional government savings bank, has realized competitive advantages over private and foreign banks by combining social policies and a focus on popular savings and credit to remain the third largest financial institution in the country. These new monetary channels provide financial roads to more social economies.

However, caution about institutional change is also in order. The Caixa has yet to be rid of two legacies: corporate centralization and capture under military rule and prolonged 
transition that still pose serious challenges for reform and democratization in Brazil. Lost institutional resources abound. Take, for example, the Revista das Caixas Econômicas (a bimonthly publication of independent savings banks published from 1949 until closed by military rulers in 1964) that published on themes such as popular savings and home finance, urban sanitation and development, municipal bond metrics, risk analysis and management, legal frameworks for savings bank operations and monetary policy. This suggests how vibrant epistemic communities and policy debates were ended by military coup in 1964. Moreover, the consolidation of 26 independent Caixas (not state banks) into a single entity corporation (sociedade anônima, S.A.) run by administrative troika under military rule shifted Caixa policies toward middle class housing and repressed alternative views.

Field research in three rural municipalities in Goiás state and Guaianases, São Paulo provided a doubly decisive case study to test theories of financial inclusion. Theoretical scenarios; aggregate data on bank performance from the Central Bank of Brazil; comparison of micro level data from Caixa branch offices and correspondents; and 182 interviews with clients, savings bank staff and management, and local citizens and authorities provide strong evidence able to leverage our causal inferences about social policy and government savings banks as new channels for financial inclusion.

Three findings stand out. First, the Caixa used institutional foundations as a large federal savings bank and principal agent for social policy provision to accelerate financial inclusion. During the 2000s, the Caixa combined the universal reach of social policies and conceptions of citizenship with the large organizational scale and extensive networks of branch offices and bank correspondents it retains as Brazil's third largest bank. Complementarities between social policy agency and savings bank operations enabled the Caixa to reach the bankless and reduce credit rationing, both in geographical terms across the remote interior of Brazil and in social terms of poor urban areas redlined by private banks.

Second, the combination of social policy agency and savings bank operations and services provided the Caixa with competitive advantages over private and foreign banks. Caixa policies such as promoting free 'no questions asked' simplified accounts, use of correspondents (over 37,000 retail institutions) and management of social policy concessions suggest that scale, scope, tradition, confidence, public bank networks and service provision based on citizenship and public policy provide institutional foundations of competitive advantage for the Caixa as a bank, especially down-market. The Caixa has used its longstanding networks and experience in home finance and construction, urban development, social policy transactions and lottery management to modernize. This is an anomaly for mainstream (and critical) theories of bank change that expected convergence toward private, market-based banking after liberalization and privatizations.

Third, mix of family grant management and simplified banking accounts suggest that political theories and popular views of basic income, citizenship, social justice and public policy have been more effective in Brazil for financial inclusion than traditional microfinance strategies designed to usher citizens into market relations through entrepreneurship. The deterioration of lower incomes and increasing poverty during economic adjustment and reforms 
in the 1990s provides further reason to take our findings about government savings banks and public policy seriously. Comparative political economy has long emphasized the difficulty of maintaining political support for implementation of reforms because the transition costs of reforms are often high, especially for those worst off. Monetary channels for change may accelerate social and financial inclusion to alleviate transition costs of economic reforms.

These three findings call for revision of core ideas about monetary policy, banking, and microfinance. Current programs for financial inclusion at the Reserve Bank of India (2010) and Bank of Indonesia (2010) have proposed issuing identity cards as bank cards for all citizens. Concepts of citizenship and public policy thus provide alternative means to significantly accelerate financial inclusion. Strong case study evidence from scenario construction, aggregate trends, bank portfolios, branch offices and correspondents, and in-depth field research in Guaianases São Paulo and Goiás state suggest that advances in monetary theory and policy and public banking provide channels less prone to fiscal constraints. Amidst the fallout of financial crisis abroad, the back to the future modernization of government savings bank operations in Brazil suggests that adjustment, economic reforms, and liberalization have provided new financial roads to more social economies and positive sum relations between democratization, monetary policy and financial inclusion.

\section{References}

AGÉNOR, Pierre-Richard; CANUTO, Otaviano. Gender equality and economic growth in Brazil: a long-run analysis. World Bank Policy Research Working Paper 6348, 2013.

AYADI, Rym et al. Investigating diversity in the banking sector in Europe: the performance and role of savings banks. Brussels: Center for European Policy Studies, 2009.

ALESINA, Alberto; SUMMERS, Laurence H. Central Bank independence and macroeconomic performance: some comparative evidence. Journal of Money, Credit and Banking, v. 25, n. 2, p. 151162, 1993.

BENNET, Andrew; ELMAN, Colin. Qualitative research: recent developments in case study methods. Annual Review of Political Science, v. 9, p. 455-476, 2006.

BERNANKE, Ben; GERTLER, Mark. Inside the black box: the credit channel of monetary policy transmission. Journal of Economic Perspectives, v. 9, n. 4, p. 27-48, 1995.

BRANDTSTÄDTER, Suzanne; WADE, Peter; WOODWARD, Kathrine. Introduction: rights, cultures, subjects and citizens. Economy and Society, v. 40, n. 2, p. 167-183, 2011.

BRESLER, Natalia; GROSSLE, Ingrid; TURNER, Anke. The role of German savings banks in preventing financial exclusion. In: ANDERLONI, Luisa; BRAGA, Maria D.; CARLUCCIO, Emanuele M. (Ed.). New frontiers in banking services. Berlin: Springer, 2007. p. 247-269.

BUTZBACH, Olivier; METTENHEIM, Kurt (Ed.). Alternative banking and financial crisis. London: Pickering \& Chatto, 2014. 
CENTRAL BANK OF BRAZIL. Relatório de Inclusão Financeira, n. 1, 2010.

CENTRAL BANK OF BRAZIL. Top 50 Banks by total assets less brokerage. Brasilia: Central Bank of Brazil. Available at: <www4.bcb.gov.br/top50/ingl/top50-i.asp>. Accessed: 30 June 2014.

COLLIER, David. Understanding process tracing. PS: Political Science and Politics, v. 44, n. 4, p. 823-830, 2011.

COLLIER, David; BRADY, Henry; SEAWRIGHT, James. Sources of leverage in causal inference: toward an alternative view of methodology. In: COLLIER, David; BRADY, Henry (Ed.). Rethinking social inquiry: diverse tools, shared standards. Lanham, MA: Rowman \& Littlefield., 2004. p. 229-266.

DE GOEDE, Marieke de. Resocialising and repoliticising financial markets: contours of social studies of finance. Economic Sociology Newsletter, May 2005.

DINIZ, Eduardo; POZZEBON, Marlei; JAYO, Martin. The role of ICT in helping parallel paths to converge: microcredit and correspondent banking in Brazil. Journal of Global Information Technology Management, v. 12, n. 2, p. 80-103, 2009.

DORNBUSCH, Rudiger; EDWARDS, Sebastian (Ed.). The macroeconomics of populism in Latin America. Chicago, IL: University of Chicago, 1991.

ECKSTEIN, Harry. Case study and theory in political science. In: POLSBY, Nelson W.; GREENSTEIN, Fred (Ed.). Handbook of political science. Reading, MA: Addison-Wesley, 1975. p. 79-137.

ESTRELLA, Juliana; RIBERIO, Leandro M. Qualidade da gestão das condicionalidades do Programa Bolsa Família: uma discussão sobre o índice de gestão descentralizada. Rev. Adm. Pública, v. 42, n. 3, p. 625-641, 2008.

FRAGA, Arminio; GOLDFAJN, Ian; MINELLA, Andre. Inflation targeting in emerging market economies. In: GERTLER, Mark; ROGOFF, Kenneth (Ed.). NBER macroeconomics annual. Cambridge: MIT, 2004. p. 365-416.

FRANCA FILHO, Genauto C.; SILVA JUNIOR, Jeová T.; RIGO, Ariádne S. Solidarity finance through community development banks as a strategy for reshaping local economies: lessons from Banco Palmas. Revista de Administração, v. 47, n. 3, p. 500-515, 2012.

GEORGE, Alexander; BENNET, Andrew. Case studies and theory development in the social sciences. Cambridge: MIT, 2005.

GOLD, David A.; LO, Clarence; WRIGHT, Erik O. Recent developments in Marxist theories of the capitalist state. Monthly Review, v. 27, n. 5, p. 29-43, 1975.

GOERTZ, Gary; MAHONEY, James. Case selection and hypothesis testing. In: GOERTZ, Gary; MAHONEY, James. A tale of two cultures: contrasting the qualitative and quantitative research paradigms. Princeton: Princeton University, 2012. p. 177-191.

HARDIE, Ian; HOWARTH, David (Ed.). Market based banking and the international financial crisis. Oxford: Oxford University, 2013. 
JAYO, Martin; DINIZ, Eduardo H. Um mapeamento descritivo dos modelos de gestão de redes de correspondentes bancários no Brasil. Revista de Administração, v. 48, n. 3, p. 621-634, 2013.

KUMAR, Anjali. Access to financial services in Brazil. Washington, DC: World Bank, 2005.

LEÃO REGO, Walquiria; PINZANI, Allesandro. Vozes do Bolsa Família. Autonomia, dinheiro e cidadania. São Paulo: Unesp, 2013.

LIJPHART, Arendt. Comparative politics and comparative method. American Political Science Review, v. 65, p. 682-693, 1971.

MAGALHAES, Reginaldo S.; ABRAMOVAY, Ricardo. A formação de um mercado de microfinanças no sertão da Bahia. Revista Brasileira de Ciências Sociais, v. 22, n. 63, p. 107-19, 2007.

MATTEI, Lauro. Microfinanças no Brasil: algumas evidências a partir de estudos de casos, Textos de Economia, v. 8, n. 1, p. 47-68, 2002.

METTENHEIM, Kurt. Federal Banking in Brazil. London: Pickering and Chatto, 2010.

METTENHEIM, Kurt. Still the century of government savings banks? The Caixa Econômica Federal. Revista de Economia Política, v. 26, n. 1, p. 39-57, 2006.

MINISTÉRIO DE DESENVOLVIMENTO SOCIAL (MDS). Bolsa Família: relatórios e estatísticas. 2010. Available at: <www.mds.gov.br/programabolsafamilia/menu_superior/relatorios_e_estatisticas/ relatorios-e-estatisticas>. Accessed: 30 June 2014.

MONZONI, Mario. Impacto em renda do microcrédito.Petrópolis: Vozes, 2008.

MOREIRA, Nathalia C. et al. Empoderamento das mulheres beneficiárias do Programa Bolsa Família na percepção dos agentes dos Centros de Referência de Assistência Social. Rev. Adm. Pública, v. 46, n. 2, p. 403-423, 2008.

NERI, Marcelo. Microcrédito: o mistério nordestino e o Grameen brasileiro. Rio de Janeiro: FGV, 2008.

NERI, Marcelo; MEDRADO, Andre L. Experimentando microcrédito: uma análise de impacto do CrediAmigo no acesso a crédito. Revista Econômica do Nordeste, v. 41, n. 1, p. 133-154, 2011.

O'DONNELL, Guillermo. Bureaucratic authoritarianism. Berkeley, CA: Institute forInternational Studies, 1973.

PAULET, Elizabeth (Ed.). Financial markets and the banking sector: roles and responsibilities in a global world. London: Pickering and Chatto, 2009.

PIERSON, Paul. Dismantling the welfare state? Reagan, Thatcher and the politics of retrenchment. Cambridge: Cambridge University, 1994.

PREFEITURA DE SÃO PAULO. Atlas Municipal. 2000. Available at: <www.prefeitura.sp.gov.br/cida$\mathrm{de} /$ secretarias/trabalho/informacoes/atlas_municipal/index.php?p=613> . Accessed: 30 June 2014. PRZEWORSKI, Adam. Capitalism and social democracy. Cambridge: Cambridge University, 1985.

PRZEWORSKI, Adam; TEUNE, Henry. The Logic of Comparative Social Inquiry. New York: WileyInterscience, 1970. 
RAGIN, Charles. The comparative method: moving beyond qualitative and quantitative strategies. Berkeley: University of California, 1987.

RESERVE BANK OF INDIA. Report of the Committee on Financial Inclusion. Delhi: Reserve Bank of India. 2008. Available at: <www.nabard.orglpdf/report_financial/Full\%20Report.pdf > . Accessed: 30 June 2014.

SCHCLARKE CURUTCHET, Alfredo. The counter-cyclical behaviour of public and private banks: an overview of the literature. In: BUTZBACH, Olivier; METTENHEIM, Kurt. (Ed.). Alternative banking and financial crisis. London: Pickering \& Chatto, 2014. p. 31-50.

SOARES, Fabio V.; RIBAS, Rafael P.; OSÓRIO, Rafael G. Evaluating the impact of Brazil's Bolsa Família: cash transfer programs in comparative perspective. Latin American Research Review, v. 45, p. 173-190, 2010.

STEINBERG, Paul. Causal assessment in Small-N policy studies. Policy Studies Journal, v. 35, n. 2, p. 181-204, 2007.

UNDP. United Nations Development Program. Atlas de desenvolvimento humano. Brasília, DF: 2013. Available at: <www.pnud.org.br/Noticia.aspx?id=3750>. Accessed: 30 June 2014.

WILLIAMSON, John. Latin American adjustment: how much has happened? Washington, DC: Institute for International Economics, 1990.

ZYSMAN, John. Governments, markets and growth: financial systems and the politics of industrial change. Ithaca, NY: Cornell University, 1983.

Kurt Eberhart von Mettenheim is Ph.D. in Political Science from Columbia University and Professor at the FGV-EAESP. E-mail: kurt.mettenheim@fgv.br.

Maria Fernanda Freire de Lima is DSc in Public Administration and Government from the FGV-EAESP and Capes scholarship — BEX process: 17280/12-5, Ministry of Education of Brazil. E-mail: fernandalima@ gvmail.br. 